\title{
Determinants of Demand for Health Care Among Sexually Transmitted Infections Patients in Kenya
}

\author{
Pauline Ogola, \\ Urbanus M. Kioko, \\ University of Nairobi, Nairobi, Kenya
}

Doi:10.19044/esj.2022.v18n8p58

Submitted: 28 January 2021

Accepted: 16 February 2022

Published: 28 February 2022
Copyright 2022 Author(s)

Under Creative Commons BY-NC-ND

4.0 OPEN ACCESS

Cite As:

Ogola P., \& Kioko U.M.,.,(2022). Determinants of Demand for Health Care Among Sexually Transmitted Infections Patients in Kenya European Scientific Journal, ESJ, 18 (8), 58. https://doi.org/10.19044/esj.2022.v18n8p58

\section{Abstract}

Globally, sexually transmitted infections (STIs) have become an enormous burden leading to high mortality and morbidity. In Kenya, various policies have been formulated to address various conditions including STIs. Individuals suffering from STIs are highly encouraged to seek medical care and avoid transmitting to uninfected individuals. In Kenya, about $14 \%$ of men and $25 \%$ of women never sought treatment for STIs or advice from any healthcare service provider. Furthermore, $42 \%$ and $23 \%$ of people with sexually transmitted infections had been symptomatic for a period of one and two weeks respectively. Although numerous studies have been conducted in many countries to establish the determinants of healthcare use among people with sexually transmitted infections, there is still very little information on the determinants of healthcare use among STI patients in Kenya. The aim of this study was to determine factors influencing health care demand for STIs in Kenya. The study analyzed data from the 2014 Kenya Demographic Household Survey (KDHS). Descriptive statistics and binary probit regression analyses were done to explore factors influencing the use of health services among STI patients in Kenya. The findings revealed that the age of the patient, sex, marital status, education levels, wealth quintiles, employment status, residence, and sex partners were statistically significant determinants of the utilization of healthcare services among STI patients in Kenya.

Keywords: Demand, determinants, STI, binary probit model, Kenya 
Sexually Transmitted Infections (STIs) are known to have a huge burden of mortality and morbidity in most developing countries (WHO), 2016). This is due to their effect on reproductive health and child health. Globally, STIs, in general, are a major health problem and their prevention is a priority since the emergence of the Human Immunodeficiency Virus (HIV) and acquired immunodeficiency syndrome (AIDS) (WHO, 2012). Previous studies have reported synergy between HIV/AIDS and STI (Singa et al., 2013; Djomand et al., 2016). In the last few decades, more than 30 sexually transmitted pathogens have been discovered, HIV being among them (Workoski et al., 2015). The World Health Organization estimates that each year there are an estimated 374 million new infections of curable STIs sesdo (chlamydia, gonorrhea, syphilis, and trichomoniasis syphilis (WHO, 2021). These infections may lead to unnecessary deaths despite the availability of cost-effective prevention methods for most of these conditions (Djomand et al., 2016). Approximately 4000 newborn babies become blind each year due to STIs infection such as gonococcal and chlamydial ophthalmia neonatorum infection (WHO, 2021.

In Sub-Saharan Africa, STIs continue to be a public health problem. According to WHO approximately 500 million in the age category 15 to 49 years have a curable STI (WHO, 2021). A study conducted in South Africa on HIV and STIs revealed that STIs are associated with an increased risk of getting HIV (Wand, et al., 2020). In Sub-Saharan Africa (SSA), various interventions have been put in place to reduce the spread and seriousness of these sexually transmitted infections (WHO, 2012). In Kenya, the burden of STIs is high and increasing (Chesang, et al., 2017). In 2012, the overall prevalence of STIs amongst individuals aged 15-64 years was estimated at $0.9 \%$. However, the population prevalence for abnormal genital discharge was $6.2 \%$ for women and $1.5 \%$ for men, while it was $9.8 \%$ and $4.6 \%$ for women and men living with HIV, respectively (NASCOP, 2014).

In many parts of Sub-Saharan Africa, only a minority of people with STIs consult public facilities. For example, among adolescent girls in a rural area of Nigeria, over $80 \%$ reported a vaginal discharge but few sought treatments (Iorkosu et al., 2020). Similarly, the Democratic Republic of Congo, (Crago, 2020) established that $87 \%$ of 1,200 commercial sex workers participating in a survey had signs and symptoms suggestive of STIs in the previous year, but only $32 \%$ had visited public health care facilities. In contrast, a population-based study in Tanzania found that nearly all men and $90 \%$ of women reporting symptoms of STI had sought treatment in the official health sector (Kerrigan et al., 2020).

Further, empirical studies at global and local levels have been undertaken to examine factors influencing the utilization of health care. Specifically, studies on STI patients have examined factors influencing patients' online 
health information-seeking behaviors (Graffigna et al., 2017), as well as the determinants of demand for health care services in Northern Ethiopia (Wellay, et al. (2018). Other studies have explored experiences of stigma related to health care in Atlanta (Eaton et al., 2018), delayed health care seeking among patients presenting STIs in HIV hotspot areas in Ethiopia (Tsadik, Lam \& Hadush, 2019), and barriers to STI service use by men in Nepal (Jahangir, et al., 2020). In Kenya, studies including Muriithi (2013) have examined determinants of care-seeking behavior in Kibera slums. Chesang et al. (2017) conducted a qualitative thematic analysis to elicit perspectives from healthcare providers in Kenya on managing sexually transmitted infections. Despite the numerous studies that have been conducted in Kenya evidence on the determinants of health care among STI patients remain scanty. This study investigates determinants of healthcare use among STI patients in Kenya.

\section{Methodology And Data}

This section discusses the theoretical framework, the estimable model, and its specifications. Description of the variables as well as a data source is provided.

\section{Theoretical framework}

Demand is an economic concept that describes a consumer's desire to pay a price for goods or services. If all other factors are constant, a rise in the price of a good or service will reduce demand while a decrease in the price of a good or service will increase demand. On the other hand, demand for health care is characterized by the level of actual consumption of goods and services by an individual facing illness/injury (Nahu, 2006; Wellay et al. 2018). This consumption could differ by demand factors such as income, cost of care, education, social norms and traditions, and the quality and appropriateness of the services provided.

Healthcare is different from other services because it is not clearly defined. In most industries, the product or service can be standardized to improve efficiency and quality. In healthcare, every consumer is structurally, chemically, and emotionally different (Halamka, 2011). What works for one person may not necessarily work for another. Healthcare also differs in terms of choosing consumers. In other services, there is a choice in selecting which person or industry business can be conducted with. It is not so in healthcare as treatment has to be provided to patients in places like the emergency room regardless of patients' ability to pay or not (Babalola, 2017).

According to the human capital model, the demand for healthcare comes from the desire of the consumer to gain good health (Grossman, 2000, Becker 1962). Most people prefer being healthy to being sick. Another factor that makes health care different from most other goods and services is that it is 
simultaneously an investment (Orayo, 2014). The money the consumer spends on being healthy today will also benefit the consumer in the future. Another key characteristic of health care is that demand is relatively inelastic (Halamka, 2011). If a consumer is sick and requires medical care, the consumer will purchase healthcare services at almost any price. The consumers' ability to purchase healthcare is ultimately limited by the customers' income, but consumers are likely to trade off spending on many other products to purchase the medical care needed.

\section{Analytical Framework}

This study applied Mwabu's framework (2007), an earlier version proposed by Rosenzweig and Schultz (1983). An STI patient is assumed to maximize the following utility function.

$U=U(X, Y, H)$

The utility depends on a health-neutral good (X), a health-related good, or an STI patient's behavior that affects his/her health (Y) and the health status $(\mathrm{H})$. The individual's (STI patient) health is produced using the following health production function.

$H=F(Y, Z, \mu)$.

Where $\mathrm{Z}$ refers to healthcare services purchased by STI patients, $\mu$ refers to the genetic and environmental factors that may affect the health status of the STI patient but which he or she has no control over and Y the healthrelated behavior. The STI patient maximizes his/her utility function subject to the health production function and the budget constraint is given as:

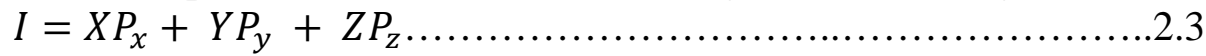

Whereby I am the exogenous income,

$P_{x}$ is the price of the health neutral good

$P_{y}$ is the price of the health-related good

$P_{Z}$ is the price of STI related services

The demand for health-related goods, non-health-related goods, and healthcare services by STI patients can be expressed as follows:

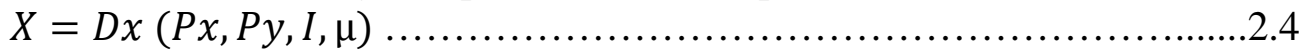

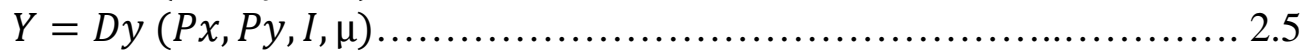

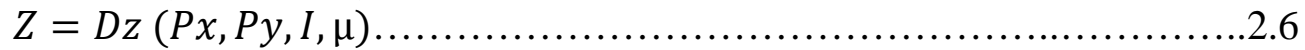

This indicates that demand for healthcare services by STI patients is a function of the price of healthcare services, price of other goods, and income.

\section{Empirical Model and Specification}

To establish an empirical relationship between various determinants and healthcare use among STI patients, the study used the probit model. The choice for this model is because the dependent variable is binary. According 
to Mwabu (2007), we assume that there exists a linear relationship between the latent variable $y^{*}$ and explanatory variables $\left(X_{i}\right)$. The structural model is stated as follows:

$y^{*}=X_{i} \beta+\varepsilon$

Where: $X_{i}$ is a vector of explanatory variables

$\beta$ is a vector of parameters to be estimated

$\varepsilon$ is the error term

Whereby $y=1$ when $y^{*}>0$

The probability of using healthcare services among STI patients as a function of a set of independent variables is given as follows:

Where:

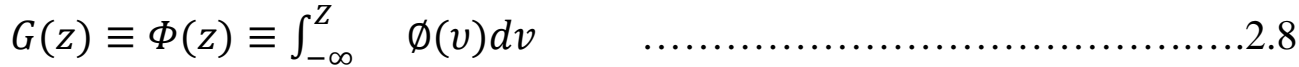

$$
\begin{aligned}
& \text { Whereas } \phi(z) \text { is the standard normal density } \phi(z)= \\
& (2 \pi)^{-1 / 2} \exp \left(-z^{2} / 2\right)
\end{aligned}
$$

The model to be estimated is specified as follows:

$y=\beta_{0}+\beta_{1} X 1+\beta_{2} X 2+\beta_{3} X 3+\beta_{4} X 4+\beta_{5} X 5+\beta_{6} X 6+\beta_{7} X 7+\beta_{8} X 8+$ $\beta_{9} X 9+\beta_{10} X 10+\beta_{11} X 11+$

$\varepsilon$.

Where $y$ is a dummy variable representing uptake of healthcare services by STI patient, $\mathrm{X} 1=$ Age, $\mathrm{X} 2=\mathrm{Sex}, \mathrm{X} 3=$ Marital Status, $\mathrm{X} 4=$ Level of Education, $\mathrm{X} 5=$ Wealth Index, $\mathrm{X} 6=$ Employment Status, $\mathrm{X} 7=$ Place of Residence. X8= Medical Insurance, X9= Religion, X10= Sex Partners X11= Autonomy in Decision Making. $\beta_{i}=$ estimated coefficients, $X_{i}=$ the various independent variables

\begin{tabular}{|c|c|c|}
\hline Variables & Definition and Measurement & Expected Sign \\
\hline $\begin{array}{l}\text { Health Care } \\
\text { Seeking for STIs } \\
\text { patients }\end{array}$ & $\begin{array}{l}\text { A dummy variable taking the value of } 1 \text { if the respondent sought } \\
\text { general healthcare services, } 0 \text { otherwise. }\end{array}$ & \\
\hline Age & Age of the respondent in completed years & Positive \\
\hline Age squared & $\begin{array}{l}\text { This is the age of the respondent squared. It measures the experience } \\
\text { of an STI patient in seeking health care. As one gets older, they are } \\
\text { more knowledgeable on why they should seek early treatment }\end{array}$ & Negative \\
\hline Sex & $\begin{array}{l}\text { This is the respondent's gender, a dummy variable taking the value of } \\
1 \text { if the respondent is male and } 0 \text { otherwise. }\end{array}$ & Negative \\
\hline Marital Status & $\begin{array}{c}\text { This is the current marital status measured as a dummy variable taking } \\
\text { the value of } 1 \text { if married, } 2 \text { if single, } 3 \text { if divorced/widowed, } 4 \text { if } \\
\text { separated. Single is the reference variable }\end{array}$ & Indeterminate \\
\hline Education Level & $\begin{array}{l}\text { This is the highest level of education attained by the respondent. It is a } \\
\text { dummy variable taking the value of } 1 \text { if the respondent has no } \\
\text { education, } 2 \text { = primary education, } 3 \text { = secondary education, and } 4 \\
\text { =post-secondary education. No education is the reference variable. }\end{array}$ & Positive \\
\hline
\end{tabular}

Table 1: Measurement and definition of variables 


\begin{tabular}{|c|c|c|}
\hline Wealth index & $\begin{array}{l}\text { A categorical variable takes the value of } 1=\text { poor, } 2=\text { middle and } \\
3=\text { rich. Poor is the reference category }\end{array}$ & Positive \\
\hline Employment & A dummy variable, 1 if employed and 0 if otherwise & Positive \\
\hline Residence & $\begin{array}{c}\text { This is the current type of residence. It is measured as a dummy } \\
\text { variable taking the value of } 1=\text { urban and } 0=\text { rural }\end{array}$ & Positive \\
\hline $\begin{array}{l}\text { Distance to } \\
\text { nearest health } \\
\text { facilities }\end{array}$ & $\begin{array}{l}\text { A dummy variable taking the value of } 1 \text { if more than } 5 \text { kilometers, and } \\
\qquad 0 \text { if less than or equal to } 5 \text { kilometers }\end{array}$ & Negative \\
\hline $\begin{array}{l}\text { Medical Insurance } \\
\text { Ownership }\end{array}$ & $\begin{array}{c}\text { A dummy variable taking the value of } 1 \text { if one has insurance, and } 0 \\
\text { otherwise }\end{array}$ & Positive \\
\hline Religion & $\begin{array}{l}\text { A dummy variable taking the value of } 1 \text { if one belongs to any religion, } \\
\qquad 0 \text { if no religion }\end{array}$ & Indeterminate \\
\hline Sex Partners & $\begin{array}{c}\text { A dummy variable taking the value of } 1 \text { if no sex partner, } 2 \text { if one sex } \\
\text { partner, and } 3 \text { if more than one sex partners }\end{array}$ & Positive \\
\hline $\begin{array}{l}\text { Autonomy in } \\
\text { Decision Making }\end{array}$ & $\begin{array}{l}\text { A dummy variable taking the value of } 1 \text { if Self-decision making on } \\
\text { own health, } 0 \text { if the decision on own health is made from spouse or } \\
\text { both }\end{array}$ & Positive \\
\hline
\end{tabular}

\section{Data Source and Type}

The study employed the latest Kenya Demographic and Health Survey (KDHS) datasets (KDHS, 2014). The KDHS contains national-level and county-level data from 40,300 households. This data contained all factors or variables for individuals seeking different types of healthcare services including for STI patients. Information contained in the dataset included demographic and socioeconomic profiles of the respondents such as education levels, age, gender, occupation, as well as health-seeking behavior. The sample for this study was obtained using a two-stage cluster sampling approach. In the first stage, 1,612 clusters were extracted from the master sampling frame. In the second stage, 25 households were systematically extracted from each cluster.

\section{Data Analysis}

The data were analyzed using STATA version 14 software. Descriptive statistics including frequency, percentage, mean, and standard deviation (SD) were done to describe the characteristics of the study sample. Probit regression analysis was done to examine the relationships between health care use among STI patients and socio-demographics self-reported health status, health facility-related factors. The results presented are the marginal effects and the coefficients show the elasticities.

\section{Results \\ 8. Socio-demographic characteristics}

The mean age of the STI patients was found to be $29 \pm 9.39$ years. More than half of the respondents were married (57\% of the respondents) and a half 
(50\%) and $28 \%$ of the respondents attained primary and secondary levels of education. Similarly, on wealth quintiles, there was a constant trend in distribution across different wealth cadres. Apart from the $23 \%$ of the respondents who were in the poorest quintile, the other four wealth categories had an almost equal distribution of wealth. The findings also showed that 57.4 percent of the respondents were working while 15.2 percent had medical insurance cover.

Table 2: Sociodemographic characteristics of the respondents

\begin{tabular}{|l|l|l|l|}
\hline Variables & Observations & Mean & Std \\
\hline Demand for healthcare services & 31,079 & .0831 & .2761 \\
\hline Age & 31,079 & 28.94 & 9.39 \\
\hline Marital Status (Married=1) & 31,079 & .5712 & .4949 \\
\hline Education Levels & & & \\
\hline No education at all & 31,079 & .1346 & .3413 \\
\hline Primary level education & 31,079 & .5024 & .5000 \\
\hline Secondary level education & 31,079 & .2766 & .4473 \\
\hline Higher education & 31,079 & .0865 & .2811 \\
\hline Wealth Index & & & \\
\hline Poorest & 31,079 & .2337 & .4232 \\
\hline Poorer & 31,079 & .1921 & .3940 \\
\hline Middle & 31,079 & .1913 & .3933 \\
\hline Rich & 31,079 & .1917 & .3936 \\
\hline Richest & 31,079 & .1912 & .3933 \\
\hline Employment status & 14,724 & .5740 & .4945 \\
\hline Medical Insurance & 14,733 & .1520 & .3591 \\
\hline Religion & & & \\
\hline No religion & 31,079 & .0163 & .1266 \\
\hline Christians & 31,079 & .8463 & .3607 \\
\hline Muslims & 31,079 & .1339 & .3405 \\
\hline Desire for More children & 13,947 & .5704 & .4950 \\
\hline Distance to a health facility & 14,735 & .7361 & .4408 \\
\hline Exposure to Mass Media & 31,079 & .8267 & .3785 \\
\hline Source Can & & \\
\hline
\end{tabular}

Source: Calculations based on KDHS data (2014)

The results of the probit regression analysis are presented in Table 3. Factors such as age $(\beta=0.1940, p$-value $=0.000)$, age squared $(\beta=-0.0031, p$ value $=0.000)$. marital status $((\beta=0.4109, p$-value $=0.000)$, having primary education $(\beta=-0.4790 ; p$-value $=0.000)$ and secondary education $(\beta=0.4463$; $p$-value $=0.000$ ) were significantly attributed to respondents' decision to use STI services. Additionally, the respondents who had university and above education level $(\beta=0.5778, p$-value $=0.000)$ were more likely to seek STI treatment compared with those with no education. 
Regarding respondents' wealth quintiles, the findings showed that those with higher incomes (second quintile; $\beta=0.2105$; $p$-value $=0.001$, third wealth quintile, $\beta=0.2315$; $p$-value $=0.000$; fourth wealth quintile $\beta=0.2791$; $p$-value $=0.000$ and fifth wealth quintile, $\beta=0.4113$, $p$-value $=0.000$ ) were likely to seek STI health services compared to those in the first quintile. At $5 \%$, the employment coefficient $(\beta=0.0918, p$-value $=0.018$ ) was positive and statistically significant indicating that being employed increased the likelihood of utilizing health care services by 0.0918. Additionally, the coefficient on sexual partners was positive and statistically significant $(\beta=-0.457, p$-value $=$ 0.043 ) showing that having more than one sex partner had a beneficial effect on STI patients seeking health care services.

Table 3: Probit Regression Results

\begin{tabular}{|c|c|c|c|c|c|c|}
\hline Demand for $\mathrm{H} / \mathrm{C}$ & Coefficients & Std. Err. & $\mathrm{z}$ & $\mathrm{P}>\mathrm{Z}$ & [95\% Conf. & Interval] \\
\hline Age & .1940 & .0162 & 11.98 & 0.000 & .1623 & .2257 \\
\hline Age Squared & -.0031 & .0002 & -12.44 & 0.000 & -.0035 & -.0026 \\
\hline $\begin{array}{l}\text { Marital Status } \\
\text { (Married=1) }\end{array}$ & .4109 & .0384 & 10.71 & 0.000 & .3357 & .4862 \\
\hline \multicolumn{7}{|l|}{ Education Level } \\
\hline Primary & .4790 & .0840 & 5.70 & 0.000 & .3143 & .6437 \\
\hline Secondary & .4463 & .0907 & 4.92 & 0.000 & .2685 & .6241 \\
\hline Higher & .5778 & .1016 & 5.69 & 0.000 & .3786 & .7770 \\
\hline \multicolumn{7}{|l|}{ Wealth Index } \\
\hline Poorer & .2105 & .0612 & 3.44 & 0.001 & .0906 & .3304 \\
\hline Middle & .2315 & .0623 & 3.71 & 0.000 & .1093 & .3536 \\
\hline Rich & .2791 & .0634 & 4.40 & 0.000 & .1549 & .4034 \\
\hline Richest & .4113 & .0668 & 6.16 & 0.000 & .2804 & .5422 \\
\hline Employment Status & .0918 & .0388 & 2.37 & 0.018 & .0159 & .1678 \\
\hline Place of Residence & .0473 & .0117 & .404 & .003 & .0241 & .489 \\
\hline Medical Insurance & .0534 & .0448 & 1.19 & 0.233 & -.0344 & .1412 \\
\hline \multicolumn{7}{|l|}{ Religion } \\
\hline Christian & .0490 & .1475 & 0.33 & 0.740 & -.2402 & .3381 \\
\hline Muslim & -.1592 & .1597 & -1.00 & 0.319 & -.4721 & .1537 \\
\hline Sex Partners & .457 & .0628 & 7.277 & .043 & .264 & .581 \\
\hline $\begin{array}{c}\text { Autonomy in Decision } \\
\text { making }\end{array}$ & .1089 & .0599 & 1.82 & 0.069 & -.0086 & .2263 \\
\hline _cons & -5.2618 & .3032 & -17.35 & 0.000 & -5.8561 & -4.6674 \\
\hline
\end{tabular}

To interpret the probit results for policy purposes, the study examined the marginal effects of the health care utilization model's factors. The marginal effects are summarized in Table 4 . The coefficient on age has a negative and statistically significant coefficient $(\beta=0.0275, p-0.000)$ at the $5 \%$ level. This means that as the respondent's age increases, the likelihood of an STI patient utilizing health care services increases by 2.75 percent. However, age squared 
( $\beta=0.0275, p$-value $=0.000$ ) has a negative and statistically significant effect at the $5 \%$ level. This indicates that the relationship between age and health care service utilization was nonlinear. The fact that the age distribution of STI patients was not linear implies that as one age, the effect on health care service utilization declines. The marital status coefficient had a positive and statistically significant effect on the use of health care services among STI patients in Kenya $(\beta=0.0584, p$ value $=0.000)$. This means that married STI patients were 5.8 percent more likely to use health care services compared to those who are not married.

The study compared individuals with primary, secondary, and tertiary education to those with no education. Primary education had a coefficient of $(\beta=0.0528, p$-value $=0.000)$, indicating that STI patients with a primary level of education were 5.28 percent more likely to use health care services than those with no education. Secondary education had a positive and statistically significant effect of health care utilisation $(\beta=0.0480, p$-value $=0.000)$. This shows that STI patients having a secondary education were 4.8 percent more likely to use health care services than those with no education. Additionally, the coefficient for higher education was positive and statistically significant $(\beta=0.0684, p$-value $=0.000)$ implying that STI patients with a higher level of education were 6.84 percent more likely to use health care services than those with no education.

Regarding wealth quintiles of STI patients, the results showed that those in the second wealth quintile $(\beta=0.0253, p$-value $=0.000)$, third wealth quintile was $(\beta=0.0282, p$-value $=0.000)$, fourth wealth quintile $(\beta=0.0352$, $p$-value $=0.000)$ and fifth wealth quintile $(\beta=0.0565, p-0.000)$ were more likely than those in the first wealth quintile to seek health care services. Employment $(\beta=0.0130, p$-value $=0.018)$ was found to be positive and statistically significant, indicating that being employed increased the likelihood of seeking health care services by 1.3 percent among STI patients. Having a sexual partner was negatively associated with seeking health care services $(\beta=-0.0783, p$ - value $=0.0443)$.

Table 4: Average Marginal Effects of health-seeking behavior among STI patients in Kenya)

\begin{tabular}{|c|c|c|c|c|c|c|}
\hline Demand health care & Marginal Effects & $\begin{array}{l}\text { Std. } \\
\text { Err. }\end{array}$ & $\mathbf{Z}$ & $\mathbf{P}>\mathbf{z}$ & $\begin{array}{l}{[95 \%} \\
\text { Conf. }\end{array}$ & Interval] \\
\hline Age & .0275 & .0023 & 11.89 & $\begin{array}{c}0.00 \\
0\end{array}$ & .0230 & .0321 \\
\hline Age Squared & -.0004 & .00004 & $\begin{array}{c}- \\
12.35\end{array}$ & $\begin{array}{c}0.00 \\
0\end{array}$ & -.0005 & -.0004 \\
\hline $\begin{array}{c}\text { Marital Status } \\
(\text { Married=1) }\end{array}$ & .0584 & .0054 & 10.66 & $\begin{array}{c}0.00 \\
0\end{array}$ & .0476 & .0691 \\
\hline \multicolumn{7}{|l|}{ Education Level } \\
\hline Primary & .0528 & .007 & 7.50 & $\begin{array}{c}0.00 \\
0\end{array}$ & .0390 & .0666 \\
\hline
\end{tabular}




\begin{tabular}{|c|c|c|c|c|c|c|}
\hline Secondary & .0480 & .0082 & 5.89 & $\begin{array}{c}0.00 \\
0\end{array}$ & .0320 & .0640 \\
\hline Higher & .0684 & .0114 & 6.00 & $\begin{array}{c}0.00 \\
0\end{array}$ & .0461 & .0908 \\
\hline \multicolumn{7}{|l|}{ Wealth Index } \\
\hline Poorer & .0253 & .0072 & 3.53 & $\begin{array}{c}0.00 \\
0\end{array}$ & .0113 & .0393 \\
\hline Middle & .0282 & .0074 & 3.83 & $\begin{array}{c}0.00 \\
0\end{array}$ & .0138 & .0427 \\
\hline Rich & .0352 & .0077 & 4.57 & $\begin{array}{c}0.00 \\
0\end{array}$ & .0201 & .0502 \\
\hline Richest & .0565 & .0089 & 6.32 & $\begin{array}{c}0.00 \\
0\end{array}$ & .0390 & .0740 \\
\hline Employment Status & .0130 & .0055 & 2.37 & $\begin{array}{c}0.01 \\
8\end{array}$ & .0022 & .0238 \\
\hline Place of Residence & .0542 & .0126 & 4.302 & $\begin{array}{c}0.03 \\
2\end{array}$ & .0372 & .0631 \\
\hline Medical Insurance & .0076 & .0064 & 1.19 & $\begin{array}{c}0.23 \\
3\end{array}$ & -.0049 & .0200 \\
\hline \multicolumn{7}{|l|}{ Religion } \\
\hline Christian & .0069 & .0202 & 0.34 & $\begin{array}{c}0.73 \\
3\end{array}$ & -.0327 & .0464 \\
\hline Muslim & -.0197 & .0212 & -0.93 & $\begin{array}{c}0.35 \\
2\end{array}$ & -.0612 & .0218 \\
\hline Sex Partners & -.0783 & .0547 & 1.431 & $\begin{array}{c}.044 \\
3\end{array}$ & .0665 & .0901 \\
\hline $\begin{array}{c}\text { Autonomy in Decision } \\
\text { making }\end{array}$ & .0029 & .0057 & 0.51 & $\begin{array}{c}0.60 \\
9\end{array}$ & -.0082 & .0140 \\
\hline -Cons & .0155 & .0085 & 1.82 & $\begin{array}{c}0.06 \\
9\end{array}$ & -.0012 & .0321 \\
\hline
\end{tabular}

\section{Discussion}

This study provides a snapshot of determining factors of health care services among sexually transmitted infections patients in Kenya. Information on factors influencing demand for STI health care services is essential to form evidence-based health policies and efficiently manage the resources in the country based on the demand and influencing factors.

The probit regression analysis revealed that having a higher educational level (secondary school and above) of STI patients increases the probability of seeking medical care than with no education. This finding is consistent with studies conducted by (Pazol, 2015), Asiimwe (2013), and (O'Donnell, 2018). These studies concluded that having a higher level of education has a significant positive effect on healthcare seeking among STI people. This might be because educated people may have better awareness about the importance of seeking medical care services. Similarly, the age of the patient is statistically significant and positively associated with health care demand. 
This implies that if the age of an STI patient were to increase by one year, the likelihood of an STI patient utilizing health care services increases by 2.75 percent. This result is supported by the studies conducted in urban Ethiopia and rural Ethiopia (Shiferaw et al. 2011).

Similarly, being married was found to be another factor statistically associated with the demand for health care services among STI patients. Married STI patients were 5.8 percent more likely to seek treatment than nonmarried patients. This finding is in-line with the study by Naing et al. (2012) which found that single individuals have a significantly lower tendency to seek medical treatment than those married. This suggests that nonmarried STI patients should be given priority in policies targeted at improving STI patients' healthcare-seeking behavior.

Economic status was also found to be a significant determinant of health care among STI patients. Patients in the richer and richest wealth quintile level were more likely to seek treatment than patients in the poorest wealth quintile. This finding highlights the complex relationship between economic status and health care service utilization. This means the lower wealth quintile is associated with reduced chances that STI patients would seek care. This finding is supported by studies conducted in Ethiopia, and Ghana (Moges et al. 2013; Adanu et al. 2008). STI patients who have a good economic status can overcome financial barriers to access health care services.

Being employed was also found to be significantly associated with increased use of healthcare services among STI patients. This implies that STI patients who are employed are more likely to pay for health care services and other associated costs than their unemployed counterparts. Grossman (1972) and (Andersen, 1995), (Wooldridge, 2020), indicated that increased incomes enable an individual to seek more health services.

\section{9. $\quad$ Strength and limitations of the study}

This analysis identified key determinants associated with the demand for health care services among STI patients. The study is based on nationally representative data with a large number of STI patients. The study has a few limitations. Information on the presence of an STI in this study is based on the self-report of STI syndromes. This may underestimate the STI burden due to two reasons. The first reason is that most STIs are asymptomatic. Therefore, respondents may not report the symptoms. The second reason is that most respondents with STIs may feel embarrassed or ashamed to admit to having STIs. Therefore, they may not report the symptoms.

\section{Conclusions}

This analysis revealed that age, marital status, education levels (primary, secondary, and post-secondary), wealth quintiles, employment 
status, residence, and the number of sex partners are all significant predictors of healthcare utilization among STI patients in Kenya. Therefore, there is a need for the government to consider addressing demand-side factors influencing the use of healthcare services among STI patients. Furthermore, health educations interventions focusing on reducing the number of sexual partners and the importance of seeking treatment for STIs are important to reduce STIs.

\section{Contribution of authors}

Pauline Ogola conceived and designed the study as well as collected and analyzed the data. Urbanus Kioko reviewed the manuscript and made additional inputs to buttress the discussion. All authors mentioned in the article approved the manuscript.

\section{References:}

1. Adanu et al. (2008). Sexually transmitted infections and health-seeking behavior among Ghanaian women in Accra. Afr J Reprod Health. 2008;12(3):151-8.,

2. Agambire, R., \& Clerk, C. (2013). Healthcare seeking and sexual behavior of clients attending the suntreso STI clinic. J Biol Agric Health, 3(10), 92-100.

3. Andersen, R. M. (1995, March). Revisiting the Behavioral Model and Access to Medical Care: Does it Matter? Journal of Health and Social Behavior, 36(1), 1-10.

4. Babalola, O. (2017). Consumers and their demand for healthcare. Journal of Health \& Medical Economics, 3(1), 6-8.

5. Becker, G. S. (1962). Investment in human capital: A theoretical analysis. Journal of political economy, 70(5, Part 2), 9-49.

6. Chesang, K., Hornston, S., Muhenje, O., Saliku, T., Mirjahangir, J., Viitanen, A... \& Bock, N. (2017). Healthcare provider perspectives on managing sexually transmitted infections in HIV care settings in Kenya: A qualitative thematic analysis. PLoS medicine, 14(12), e1002480.

7. Crago, A. L. (2020). Chercher La Vie: Births, Deaths, Labour and Militarized Border-Crossing among Sex Workers in an Area of Armed Conflict in Eastern Democratic Republic of Congo (Doctoral dissertation).

8. Debrah Asiimwe, G. O. (2013). Prevalence and Risk Factors Associated with Type 2 Diabetes in Elderly Patients Aged 45-80 Years at Kanungu District. Journal of diabetes research. Retrieved 2021

9. Djomand, G., Gao, H., Singa, B., Hornston, S., Bennett, E., Odek, J \& Bock, N. (2016). Genital infections and syndromic diagnosis among 
HIV-infected women in HIV care programs in Kenya. International Journal of STD \& AIDS, 27(1), 19-24.

10. Eaton, L. A., Earnshaw, V. A., Maksut, J. L., Thorson, K. R., Watson, R. J., \& Bauermeister, J. A. (2018). Experiences of stigma and health care engagement among Black MSM newly diagnosed with HIV/STI. Journal of behavioral medicine, 41(4), 458-466.

11. Dagnew GW, Asresie MB, Fekadu GA, Gelaw YM (2020) Factors associated with the divorce from the first union among women in Ethiopia: Further analysis of the 2016 Ethiopia demographic and health survey data. PLoS ONE 15(12): e0244014. https://doi.org/10.1371/journal.pone.0244014.

12. Graffigna, G., Barello, S., Bonanomi, A., \& Riva, G. (2017). Factors affecting patients' online health information-seeking behaviors: The role of the Patient Health Engagement (PHE) Model. Patient education and counseling, 100(10), 1918-1927.

13. Grossman, M. (1972). On the concept of health capital and the demand for health. Journal of Political economy, 80(2), 223-255.

14. Grossman, M. (2000). The human capital model. In Handbook of health economics (Vol. 1, pp. 347-408). Elsevier.

15. Halamka, J. (2011). Healthcare is different. Life as a Healthcare CIO Blog.

16. Iorkosu, T. S., Emmanuel, V. O., Benjamin, G. A., Tsembe, D. D., Aluka, T. M., \& Ajai, F. (2020). Utilization of Traditional Medication for the Treatment of Vaginal Infection among Women of Reproductive Age in Makurdi Metropolis of Benue State, Nigeria.

17. Kerrigan, D., Donastorg, Y., Barrington, C., Perez, M., Gomez, H., Mbwambo, J., ... \& Karver, T. S. (2020). Assessing and Addressing Social Determinants of HIV among Female Sex Workers in the Dominican Republic and Tanzania through Community empowerment-based Responses. Current HIV/AIDS Reports, 1-9.

18. Muriithi, M. K. (2013). The determinants of health-seeking behavior in a Nairobi slum, Kenya. European Scientific Journal, 9(8).

19. Moges B, Yismaw G, Kassu A, Megabiaw B, Alemu S, Amare B, Muluye D. Sexually transmitted infections based on the syndromic approach in Gondar town, northwest Ethiopia: a retrospective study. BMC Public Health. 2013;13(1):143

20. Mwabu, G. (2007, May). Health Economics for Low-Income Countries. Yale University Economic Growth Center Discussion Paper No. 955, Available at SSRN: https://ssrn.com/abstract=988379.

21. Mwabu, A. K. (2010). Human Development in Africa. Human Development Research Papers (2009 to present) HDRP-2010-08. 
Human Development Report Office (HDRO), United Nations Development Programme (UNDP).

22. Nahu, A. (2006). Determinants of demand for health care services and their implication on Health care financing: the case of Bure town. Ethiopian Journal of Economics, 11(683-2016-46848), 89-122.

23. Naing, T, Geater, A, Pungrassami, P. 2012] Migrant workers' occupation and healthcare-seeking preferences for TB-suspicious symptoms and other health problems: a survey among immigrant workers in Songkhla province, southern Thailand. BMC Int Health Hum Rights. 2012;12:22. Google Scholar |Crossref] research

24. National AIDS and STI Control Programme (2014). Kenya AIDS indicator survey 2012: final report. Nairobi: NASCOP.

25. Orayo, J. A. (2014). Determinants of Health insurance demand among the migrants in Kenya (Doctoral dissertation, University of Nairobi).

26. O'Donnell O (2018). Access to health care in developing countries: breaking down demand-side barriers. Cad Saude Publica. 2007;23(12):2820- 2834; Prosser Trish. Utilization of Health and Medical Services: Factors influencing health care seeking behavior and unmet needs in rural areas of Kenya. Theses Dr. Masters. 2007. http://ro.ecu.edu.au/ theses/46. Accessed October 3, 2018].

27. Pazol, Z. T.-S. (2015). Impact of Contraceptive Education on Contraceptive Knowledge and Decision Making: A Systematic Review. Pubmed.

28. Pokhrel, S., \& Sauerborn, R. (2004). Household decision-making on child health care in developing countries: the case of Nepal. Health Policy and Planning, 19(4), 218-233.

29. Ramchandani, M. S., \& Golden, M. R. (2019). Confronting rising STIs in the era of PrEP and treatment as prevention. Current HIV/AIDS Reports, 16(3), 244-256.

30. Schultz, T. W. (1961). Investment in human capital. The American economic review, 1-17.

31. Shiferaw, Y., Alemu, A., Girma, A., Getahun, A., Kassa, A., Gashaw, A., ... \& Gelaw, B. (2011). Assessment of knowledge, attitude, and risk behaviors towards HIV/AIDS and other sexually transmitted infections among preparatory students of Gondar town, northwest Ethiopia. BMC research notes, 4(1), 505.

32. Singa, B., Glick, S. N., Bock, N., Walson, J., Chaba, L., Odek, J. \& John-Stewart, G. (2013). Sexually transmitted infections among HIVinfected adults in HIV care programs in Kenya: a national sample of HIV clinics. Sexually transmitted diseases, 40(2), 148.

33. Tsadik, M., Lam, L., \& Hadush, Z. (2019). Delayed health care seeking is high among patients presenting with sexually transmitted infections 
in HIV hotspot areas, Gambella town, Ethiopia. HIV/AIDS (Auckland, NZ), 11, 201.

34. Wand, H., Reddy, T., Dassaye, R., Moodley, J., Naidoo, S., \& Ramjee, G. (2020). Estimating prevalence and incidence of sexually transmitted infections among South African women: Implications of combined impacts of risk factors. International Journal of STD \& AIDS, 31(11), 1093-1101.

35. Wanyoike A. N (2016). Determinants of Demand for Healthcare Services in Private Hospitals in Kenya (Doctoral dissertation, University of Nairobi).

36. Wellay, T., Gebreslassie, M., Mesele, M., Gebretinsae, H., Ayele, B., Tewelde, A., \& Zewedie, Y. (2018). Demand for health care service and associated factors among patients in the community of Tsegedie District, Northern Ethiopia. BMC health services research, 18(1), 697.

37. Wooldridge, J. M. (2020). Introductory econometrics, A modern approach (7th ed.).

38. Workowski, K. A., \& Bolan, G. A. (2015). Sexually transmitted diseases treatment guidelines, 2015. MMWR. Recommendations and reports: Morbidity and mortality weekly report. Recommendations and reports, 64(RR-03), 1.

39. World Health Organization (2016). Global Health Sector Strategy on Sexually Transmitted Diseases; Geneva: WHO.

40. World Health Organization (2012). Global incidence and prevalence of selected curable sexually transmitted infections-2008.

41. World Health Organization (2021). Sexually transmitted infections (STIs). Sexually transmitted infections (STIs) (who.int). 